\title{
Meningkatkan Pengetahuan Dan Sikap Generasi Milenial terhadap Credit Union Dengan Pendekatan Cognitive Behavior
}

\author{
Bartolomeus Yofana Adiwena ${ }^{1}$, Eugenius Tintus Reinaldi ${ }^{2}$, Lucia Trisni Widhianingtanti ${ }^{3}$ \\ ${ }^{1,2.3}$ Univeristas Katolik Soegijapranata \\ adiwena@unika.ac.id \\ eugeniusreinaldi@unika.ac.id \\ luciatrisni@gmail.com
}

\begin{abstract}
Abstrak: Credit Union (CU) merupakan lembaga keuangan mikro yang didasarkan pada tiga prinsip, yaitu kemandirian, kebersamaan, dan pendidikan. CU adalah salah satu pilar utama perekonomian Indonesia yang membantu masyarakat mengembangkan bisnis dan memberikan literasi keuangan kepada anggotanya. Agar operasi CU dapat tetap berlanjut, CU perlu memperluas pasarnya. Salah satu target ekspansi pasar mereka adalah generasi milenial yang saat ini dan ke depannya akan mendominasi persentase penduduk Indonesia. Sayangnya, saat ini banyak kaum milenial yang belum mengetahui tentang CU dan kurang memahami dampak positif yang dimiliki CU. Tujuan dari program ini adalah untuk mengenalkan CU kepada para milenial agar terjadi perubahan sikap para milenial terhadap CU. Program ini dilaksanakan dalam dua hari, hari pertama adalah ceramah oleh narasumber berpengalaman yang diakhiri dengan pembuatan rencana aksi (action plan) pribadi, sedangkan hari kedua merupakan diskusi tentang rencana aksi tersebut. Peserta program ini terdiri dari 33 orang generasi milenial. Perbedaan sikap peserta antara sebelum dan sesudah pelatihan diuji dengan uji on-parametrik Wilcoxon signed-rank test. Hasilnya menunjukkan bahwa ada peningkatan sikap secara keseluruhan (untuk mengikuti CU dan berwirausaha) pada peserta. Dapat disimpulkan bahwa program ini berhasil meningkatkan minat peserta untuk mengikuti CU dan berwirausaha.
\end{abstract}

Kata kunci: cognitive-behavior, credit union, koperasi, generasi milenial

\begin{abstract}
Credit Union (CU) is a microfinance institution that is based on three principles, namely independence, solidarity, and education. $\mathrm{CU}$ is one of the key pillars of the Indonesian economy that helps people develop their businesses and provides financial literacy to their members. In order for $C U$ operations to remain sustainable, $C U$ needs to expand its market. One of the targets for their market expansion is the millennial generation, which in the next few years will dominate Indonesia's population. Unfortunately, nowadays many millennials do not know about $C U$ and do not understand the positive impact it has. The purpose of this program is to introduce $C U$ to the millennials so that there is an attitude change of millennials in regard to $C U$. This program is conducted in two days, the first day is a lecture by experienced speakers and ends with the making of the personal action plan, while the second day is the discussion about their action plan. Participants consisted of 33 millennials. The difference in Millenials' attitudes between the before and after training was tested by the non-parametric Wilcoxon signed-rank test. Results showed that there was an increase in overall attitudes (to join $C U$ and entrepreneurship) among the participants. It can be concluded that this program succeeded in increasing participants' interest in joining $C U$ and entrepreneurship.
\end{abstract}

Keywords: cognitive-behavior, credit union, cooperatives, millenial generation

\section{PENDAHULUAN}

Credit Union (CU) merupakan lembaga keuangan mikro yang bergerak di bidang simpan pinjam, namun dimiliki bersama oleh anggotanya dan bertujuan menyejahterakan anggotanya. CU cukup berbeda dengan koperasi simpan pinjam konvensional, di mana CU beroperasi 
berdasarkan tiga prinsip, yaitu prinsip swadaya, solidaritas, dan pendidikan. Berdasarkan prinsip swadaya, sumber modal atau dana pengembangan usaha CU hanya berasal dari tabungan anggotanya sendiri. Prinsip solidaritas berarti CU memberikan layanan simpan pinjam, asuransi, dan perlindungan kesejahteraan untuk anggotanya. Sedangkan, prinsip pendidikan berarti CU secara konsisten dan berkala menyelenggarakan program pendidikan bagi anggotanya, seperti pengelolaan keuangan keluarga dan fasilitasi usaha rumah tangga.

Selain memiliki fungsi utama mengembangkan usahanya, CU juga memiliki fungsi sosial melayani masyarakat miskin dan rentan miskin, sehingga dapat lebih produktif secara ekonomi (Inkopdit, 2018). Fungsi sosial inilah yang menjadi ciri khas CU sebagai lembaga keuangan yang tidak hanya berorientasi pada profit semata, tapi juga kesejahteraan sosial. CU memiliki tanggung jawab membangun dan mewujudkan keadilan sosial dan manusia bagi individu anggota dan masyarakat dimana CU berada dan bekerja. Layanan CU dapat dimanfaatkan oleh anggota yang miskin dan rentan miskin untuk mengamankan konsumsi, mengatasi kondisi darurat, sumber modal untuk mancari peluang usaha, serta membayar pengeluaran penting lainnya.
CU yang menjadi mitra dalam program ini adalah CU Pelita Usaha cabang Semarang dan CU Pangudi Luhur Kasih Semarang. CU Pelita Usaha didirikan di Temanggung pada 1 April 2002. CU ini perlahan-lahan berkembang bersama masyarakat setempat dan memperoleh legalisasi sebagai badan hukum pada tahun 2006. CU yang berkantor pusat di J1. Sri Suwarno No.1 Temanggung ini memiliki delapan cabang pelayanan yang tersebar di Semarang, Bandungan, dan Parakan. Di sisi lain, CU Pangudi Luhur Kasih terbentuk pada tanggal 1 Mei 2010 di Semarang. CU Pangudi Luhur Kasih telah memiliki cabang pelayanan di beberapa kota, seperti Semarang, Yogyakarta, Ambarawa, Klaten, dan Jakarta.

Koperasi, termasuk CU, merupakan salah satu pilar kunci perekonomian Indonesia karena dapat membantu masyarakat mengembangkan usahanya, meningkatkan pendapatan dan taraf hidup anggotanya, serta memberikan kecerdasan finansial kepada anggotanya (Ervina, 2019). Melalui CU, terwujudlah demokrasi ekonomi, yaitu kebersamaan dan gotong royong dalam perekonomian. Melalui CU, perekonomian dapat dihidupkan oleh masyarakat dan juga menghidupkan masyarakat. Namun demikian, kenyataannya saat ini banyak CU yang kondisinya belum sebaik lembaga 
keuangan lainnya karena masih banyak masyarakat, khususnya generasi milenial, yang kurang memahami dan tertarik pada kegiatan usaha koperasi (Zulhartati, 2010).

Generasi milenial sedang menjadi pusat perhatian dalam berbagai bidang kehidupan masyarakat. Generasi milenial adalah mereka yang dilahirkan antara tahun 1980 sampai 2000 (saat ini berusia 21 sampai 41 tahun) dengan karakteristikkarakteristik khas dibandingkan generasi sebelumnya seperti baby boomers dan generasi X (Kemenpppa, 2018). Menurut data Alvara (2020), generasi milenial dikenal memiliki loyalitas yang tergolong rendah. Saat dihadapkan pada produk baru yang lebih menarik, generasi milenial akan dengan mudah berpaling karena mereka sangat reaktif terhadap hal baru yang dinilai lebih memberikan peluang dan menguntungkan mereka. Generasi milenial mampu bekerja dengan lebih cepat dan cerdas lantaran didukung oleh keberadaan teknologi. Perkembangan teknologi juga mendorong milenial memiliki kemampuan multitasking dan sangat lekat dengan internet. Generasi milenial dapat menggunakan internet dengan durasi lebih dari tujuh jam per hari. Dalam bidang keuangan dan pengeluaran, generasi milenial cenderung lebih konsumtif, memiliki pengeluaran yang tinggi untuk telekomunikasi dan gaya hidup yang tinggi, mengalahkan pengeluaran untuk kebutuhan tabungan dan investasi.

CU memiliki tantangan besar untuk mengoptimalkan potensi generasi milenial di Indonesia (Prayogo, 2019). Apalagi, Indonesia akan memasuki masa bonus demografi selama rentang waktu 20202035 dimana komposisi penduduk Indonesia akan didominasi oleh generasi milenial. CU harus mampu menarik minat memenuhi tuntutan generasi milenial yang butuh kepraktisan, kecepatan, dan efektivitas, namun tanpa mengurangi kualitas dan kredibilitas CU. Menurut salah satu pengurus CU Pelita Usaha cabang Semarang, mereka mengalami kesulitan menarik minat generasi muda untuk bergabung dengan CU mereka. Selama ini generasi muda menganggap bahwa koperasi dan CU adalah lembaga keuangan untuk orang tua. Meskipun CU Pelita Usaha sudah memulai inovasi layanan menggunakan aplikasi daring, penggunaannya oleh generasi muda masih sangat minim. Generasi muda menganggap bahwa bank umum lebih menarik dan aman dibandingkan dengan CU.

Keberhasilan CU saat ini dan ke depannya tergantung kepada partisipasi para anggotanya. Anggota yang berperan sebagai pemilik dan pengguna dana merupakan jantung CU. Tanpa keterlibatan anggota, CU tidak akan dapat berjalan dan 
bertahan. Sekretaris Kementerian Koperasi dan UKM, Rully Indrawan, mengatakan agar sektor koperasi dapat terus eksis dalam perekonomian Indonesia, koperasi harus mengakomodasi kebutuhan dan karakter generasi milenia (Prayogo, 2019). Jika kondisi ini tidak segera ditangani, CU akan ditinggalkan oleh generasi muda dan terancam mengalami kepunahan di Indonesia.

Selain pengakraban terhadap CU dan program-programnya, salah satu hal penting yang juga perlu diberikan kepada generasi milenial saat ini adalah literasi finansial. Literasi finansial merupakan kemampuan seseorang untuk mencari dan mengakses pengetahuan yang cukup tentang finansial untuk mengevaluasi informasi dan pilihan situasional yang tersedia, sehingga dapat mengambil keputusan terkait finansial dengan percaya diri dan akurat untuk mencapai well-being finansial (Faulkner, 2015). Beberapa keterampilan finansial yang perlu dimiliki generasi milenial seperti memahami pemasukan dan pengeluaran, membuat goal finansial serta keputusan pengeluaran yang bijak, memahami strategi menabung, pilihan investasi, serta metode asesmen risiko, dan memahami opsi kredit serta pertimbangan penting dalam membeli atau menyewa asset.
Faulkner (2015) menyatakan bahwa untuk generasi yang lebih muda, masa depan finansial cenderung tidak menentu. Hal ini diakibatkan semakin tingginya biaya pendidikan, bursa kerja yang kompetitif, gaya hidup yang berubah, dan biaya hidup semakin meningkat. Bahkan hal ini akan menyulitkan dan memberi tekanan untuk mereka yang dianggap telah melek finansial. Hingga saat ini tercatat bahwa generasi milenial secara rata-rata menyisihkan hanya 10,7 persen dari pendapatan mereka untuk ditabung, sedangkan 51,1 persen pendapatan habis untuk kebutuhan para milenial (IDN Research Institute, 2019). Survei tersebut juga memaparkan bahwa minat generasi milenial terhadap investasi masih rendah dengan persentase hanya sebesar dua persen. Dari hasil survei tersebut, generasi milenial tergolong konsumtif menggunakan uang atau pendapatannya.

$$
\text { Pangestu \& Karnadi }
$$

menemukan bahwa literasi finansial ternyata mempengaruhi keputusan menabung pada mahasiswa di Indonesia. Seseorang yang memiliki literasi finansial yang baik akan mampu mengatur keuangannya dengan baik pula, termasuk menabung untuk keperluan masa depan maupun investasinya. Sementara faktorfaktor yang mempengaruhi literasi finansial antara lain usia, jenis kelamin, dan program 
studi. Semakin tua usia seseorang, maka skor literasi finansialnya semakin tinggi. Sementara untuk jenis kelamin, skor literasi finansial perempuan cenderung lebih rendah dibandingkan skor literasi finansial laki-laki. Mahasiswa dari program studi ekonomi dan bisnis memiliki skor literasi finansial yang cenderung lebih tinggi dibandingkan mahasiswa dari prodi lain.

Di Malaysia, Khan, Tan, \& Gan (2018) menemukan bahwa laki-laki generasi Y yang lebih muda, etnis China, punya title sarjana, dan berpengalaman sebagai investor memiliki literasi finansial yang lebih tinggi. Semakin tinggi tingkat literasi finansial seseorang, maka ia cenderung lebih berhati-hati dalam membuat keputusan untuk berinvestasi, khususnya dalam investasi yang berisiko tinggi. Meskipun demikian, penelitian Khan, dkk. (2018) juga menunjukkan bahwa semakin tinggi tingkat literasi finansial seseorang, maka semakin besar juga imbal balik di portofolio investasinya.

Dari berbagai penelitian sebelumnya, peneliti menyimpulkan bahwa pengenalan terhadap $\mathrm{CU}$ dan literasi keuangan adalah dua hal esensial yang saling berhubungan dan tidak dapat dipisahkan. Seseorang dengan literasi keuangan yang rendah tentu tidak akan terlalu memikirkan pengelolaan keuangannya. Sebaliknya, orang dengan literasi keuangan yang baik pasti akan memikirkan pengelolaan keuangannya dengan cermat, dan CU menjadi salah satu alternatif menarik yang dapat dipilih dalam pengelolaan keuangannya. Oleh karena itu, pengabdian kepada masyarakat ini dilakukan dalam bentuk sosialisasi kepada generasi milenial. Sosialisasi yang dilakukan memiliki dua sasaran utama, yaitu memberikan pendidikan atau pelatihan tentang literasi keuangan agar generasi milenial lebih cerdas mengelola keuangan mereka di masa yang sulit ini, khususnya akibat pandemi COVID-19, serta memperkenalkan CU kepada generasi milenial, sehingga mereka mengenal dan tertarik untuk merancang masa depan keuangan mereka bersama CU.

\section{METODE PELAKSANAAN PENGABDIAN}

Program pengabdian masyarakat ini menargetkan ranah pengetahuan atau kognitif generasi milenial. Kognisi di sini adalah perilaku tidak tampak (covert behavior) yang merujuk pada proses-proses yang tidak terlihat secara langsung, seperti pikiran, keyakinan, dan sikap seseorang. Meskipun tidak tampak, tapi kognisi sangat mempengaruhi perilaku seseorang seharihari.

Pengabdian masyarakat ini dirancang berdasarkan teknik cognitive 
behavior. Teknik cognitive behavior terdiri dari dua jenis. Pertama, teknik yang berfokus mengubah kognisi seseorang, dengan harapan bahwa akan diikuti dengan perubahan perilaku. Kedua, teknik yang berfokus pada merubah perilaku, dengan harapan bahwa akan diikuti dengan perubahan kognisi (Sundel \& Sundel, 2005). Dalam program ini, kami berfokus pada usaha untuk mengubah perilaku generasi milenial agar kognisinya dapat turut berubah perlahan-lahan. Program ini terdiri dari self-instructional training dan problem-solving therapy. Self-instructional training adalah bentuk modifikasi cognitive behavior yang fokusnya pada menolong individu agar dapat meningkatkan kemampuan coping. Dalam program ini, trainer akan melatih individu agar dapat memberi instruksi untuk diri mereka sendiri agar dapat menghadapi situasi sulit dengan efektif (Sundel \& Sundel, 2005). Setelah itu dibutuhkan latihan cognitive behavior untuk memfasilitasi terjadinya transfer instruksi dari trainer agar menjadi instruksi-diri (self-instruction), dimana peserta akan berbicara dan memotivasi diri sendiri.

Program ini dilaksanakan sebanyak dua hari, yaitu Jumat, 4 Desember 2020 dan Senin, 7 Desember 2020 selama sekitar dua setengah jam per harinya. Pada hari pertama, peserta diberikan materi dasar tentang financial literacy. Setelah itu, peserta diajak untuk berkenalan dengan CU dan apa saja yang bisa dilakukan dengan menjadi anggota CU. Kedua materi tersebut diberikan oleh dua orang profesional di bidang perkoperasian dan wirausaha. Setelah pemberian materi dasar, peserta diberikan materi tentang self-instructional dan problem solving oleh trainer profesional. Tujuannya agar peserta dapat menghadapi situasi sulit dengan efektif melalui instruksi dan motivasi diri.

Setelah pemaparan materi, program pengabdian ini dilanjutkan dengan praktek membuat rencana aksi (action plan) individual, khususnya terkait literasi keuangan dan CU. Rencana aksi yang diminta terkait dengan SWOT dan SMART Goal, agar peserta mengenali kelebihan dan kekurangan yang ada dalam dirinya, lalu menggunakan modal-modal tersebut untuk menyusun tujuan atau rencana mereka, baik jangka panjang maupun tujuan jangka pendek. Peserta diminta membuat rencana aksi dalam waktu 1 hari dan akan dibahas bersama pada hari kedua.

$$
\begin{array}{rr} 
& \text { Kegiatan hari kedua dilakukan } \\
\text { untuk berbagi (sharing) tentang }
\end{array}
$$
pengalaman peserta membuat rencana aksi dan memberikan umpan balik dari fasilitator kegiatan. Tiga peserta dipilih untuk membagikan rencana aksi yang telah mereka tuliskan dan kesulitan yang dialami. 
Setiap orang diberikan waktu kurang lebih 5 menit untuk presentasi. Proses ini menjadi sangat penting karena seluruh peserta dapat berbagi kendala yang nyata dan memperoleh opsi solusi yang relevan dari fasilitator kegiatan. Setelah proses sharing selesai, kegiatan dilanjutkan dengan sesi penguatan sebelum program ini ditutup. Materi sesi ini berjudul "Seven Habit", yaitu materi tentang bagaimana mengubah kebiasaan kita agar rencana aksi yang sudah dibuat dapat dijalankan dengan penuh komitmen. Seven habit terdiri dari: Menjadi proaktif, berorientasi pada tujuan, membuat pskala rioritas, optimis, memahami situasi, bersinergi, dan mengasah gergaji untuk mendapat semangat dan kesegaran. Evaluasi atas efektivitas program ini menggunakan metode pre-test dan posttest. Kegiatan ini dianggap berhasil apabila terdapat peningkatan pengetahuan, sikap, dan intensi bergabung dengan $\mathrm{CU}$ yang ditunjukkan peserta. Perubahan pengetahuan, sikap, dan intensi bergabung dengan CU diukur dengan alat ukur yang dikembangkan oleh peneliti (Tabel 1). Seluruh data yang diperoleh dianalisis menggunakan perangkat lunak JASP for Mac.

\section{HASIL PENGABDIAN}

Peserta yang mengisi daftar hadir pada pelaksanaan kegiatan hari pertama berjumlah 59 orang. Sedangkan, peserta yang mengisi daftar hadir pada pelaksanaan di hari kedua berjumlah 49 orang. Dari jumlah yang hadir, peserta yang hadir pada kedua sesi dan mengisi pre-test dan posttest berjumlah 33 orang. Peserta didominasi oleh generasi milenial yang sudah bekerja atau memiliki usaha.

Efektivitas keseluruhan program diukur dengan melihat perubahan sikap peserta pelatihan dan dan evaluasi atau tanggapan peserta terhadap pelaksanaan program pelatihan ini. Perubahan sikap peserta diukur dengan alat ukur yang dikembangkan oleh peneliti (Tabel 1). Alat pengukuran sikap terdiri dari dua dimensi, yaitu sikap terhadap CU yang memiliki tujuh butir pernyataan, dan dimensi sikap berwirausaha yang memiliki tiga butir pernyataan. Kesepuluh butir pernyataan berbentuk skala Likert dengan 7 pilihan (sangat tidak sesuai - sangat sesuai).

Peneliti juga menanyakan tanggapan dan kepuasan peserta atas jalannya kegiatan ini menggunakan formulir evaluasi reaksi melalui Google Form. Alat ukur ini berdasarkan dari saran Kirkpatrick (2006) yang terdiri dari 15 item. Aspek yang diukur yang mencakup isi pelatihan, sarana dan prasarana, trainer, jadwal pelaksanaan pelatihan dan pelaksanaan pelatihan. Rentang jawaban 
yang disediakan, mulai dari 1 = "sangat

tidak puas", hingga 5= "sangat puas".

Tabel 1 Butir pengukuran sikap dan mean

\begin{tabular}{|c|c|c|c|}
\hline \multirow[t]{2}{*}{ No } & \multirow[t]{2}{*}{ Item } & \multicolumn{2}{|c|}{ Mean } \\
\hline & & Sebelum pelatihan & Setelah pelatihan \\
\hline 1 & $\begin{array}{l}\text { Saya sudah memiliki pengetahuan tentang } \\
\text { Credit Union }\end{array}$ & 4,394 & 5,818 \\
\hline 2 & $\begin{array}{l}\text { Saya mengetahui syarat-syarat untuk menjadi } \\
\text { anggota Credit Union }\end{array}$ & 4,939 & 6,121 \\
\hline 3 & $\begin{array}{l}\text { Saya memiliki keinginan untuk bergabung } \\
\text { menjadi anggota Credit Union }\end{array}$ & 6,394 & 6,515 \\
\hline 4 & $\begin{array}{l}\text { Saya ingin mengajak orang dekat saya gabung } \\
\text { jadi anggota Credit Union }\end{array}$ & 5,697 & 5,970 \\
\hline 5 & $\begin{array}{l}\text { Menurut saya, bergabung dengan Credit } \\
\text { Union adalah hal yang mudah }\end{array}$ & 6,030 & 6,273 \\
\hline 6 & $\begin{array}{l}\text { Bergabung dengan Credit Union akan } \\
\text { bermanfaat untuk saya }\end{array}$ & 6,333 & 6,515 \\
\hline 7 & $\begin{array}{l}\text { Menurut saya, Credit Union memiliki fungsi } \\
\text { yang penting di tengah masyarakat }\end{array}$ & 6,394 & 6,606 \\
\hline 8 & Saya memiliki keinginan untuk berwirausaha & 6,121 & 6,182 \\
\hline 9 & $\begin{array}{l}\text { Menurut saya, mencari modal berwirausaha } \\
\text { adalah hal yang tidak sulit }\end{array}$ & 5,273 & 5,303 \\
\hline 10 & $\begin{array}{l}\text { Saya memiliki peluang yang besar untuk } \\
\text { berwirausaha }\end{array}$ & 5,788 & 5,939 \\
\hline
\end{tabular}

\section{Perbandingan sikap keseluruhan} sebelum dan setelah pelatihan

Data sikap keseluruhan tidak terdistribusi secara normal, terbukti dengan hasil pengujian normalitas Shapiro-Wilk yang signifikan $(\mathrm{W}=0,932 ; \mathrm{p}<0,05)$. Oleh karena itu, peneliti menguji perbedaan mean sikap keseluruhan antara sebelum pelatihan dengan setelah pelatihan menggunakan pengujian non parametrik Wilcoxon signed-rank. Seperti dapat dilihat pada tabel 2, mean sikap keseluruhan para peserta setelah mengikuti pelatihan ternyata lebih tinggi $( \pm 6,8 \%)$ daripada mean sikap keseluruan sebelum pelatihan. Perbedaan mean tersebut terkonfirmasi secara statistik. Dengan demikian, dapat disimpulkan 
bahwa terdapat perbedaan mean sikap keseluruhan antara sebelum pelatihan dengan setelah pelatihan. Data dapat dilihat pada tabel 3

\section{Perbandingan sikap terhadap CU sebelum dan setelah pelatihan}

Peneliti menemukan bahwa data sikap terhadap CU juga tidak terdistribusi secara normal $(\mathrm{W}=0,900 ; \mathrm{p}<0,05)$. Oleh karena itu, peneliti menguji perbedaan mean sikap sikap terhadap CU antara sebelum pelatihan dengan setelah pelatihan menggunakan pengujian non parametrik Wilcoxon signed-rank. Analisis menunjukkan bahwa mean sikap terhadap CU setelah mengikuti pelatihan ternyata lebih tinggi $( \pm 8,8 \%)$ daripada mean sikap terhadap CU sebelum pelatihan, dan perbedaan tersebut signifikan secara statistik. Dengan demikian, peneliti menyimpulkan bahwa terdapat perbedaan mean sikap terhadap CU antara sebelum pelatihan dengan setelah pelatihan. Data dapat dilihat pada tabel 3 .

\section{Perbandingan sikap untuk berwirausaha sebelum dan setelah pelatihan}

Data sikap untuk berwirausaha terdistribusi secara normal (W=0,965; $\mathrm{p}=\mathrm{n} . \mathrm{s})$. Peneliti menggunakan analisis t-test untuk menguji perbedaan mean sikap untuk berwirausaha antara sebelum pelatihan dengan setelah pelatihan. Seperti dapat dilihat pada tabel 2, mean sikap untuk berwirausaha setelah mengikuti pelatihan lebih tinggi ( $\pm 1,3 \%)$ daripada mean sikap terhadap CU sebelum pelatihan. Namun, perbedaan tersebut tidak terkonfirmasi secara statistik. Dengan demikian, peneliti menyimpulkan bahwa tidak terdapat perbedaan mean sikap untuk berwirausaha antara sebelum pelatihan dengan setelah pelatihan. Data dapat dilihat pada tabel 3.

Tabel 2 Hasil pengujian normalitas

\begin{tabular}{lcc}
\hline \multirow{2}{*}{ Variabel Demografis } & \multicolumn{2}{c}{ Shapiro-Wilk Test } \\
\cline { 2 - 3 } & Statistic & Sig. \\
\hline Sikap keseluruhan & 0.932 & 0.039 \\
Sikap terhadap CU & 0.900 & 0.005 \\
SIkap berwirausaha & 0.965 & 0.361 \\
\hline
\end{tabular}


Patria : Jurnal Pengabdian Kepada Masyarakat

ISSN : 2656-5455 (media online) Vol. 3 | No. 2 September 2021

Tabel 3 Hasil uji beda mean sikap peserta sebelum dan setelah pelatihan

\begin{tabular}{lcccccc}
\hline & \multicolumn{2}{c}{ Pre test } & \multicolumn{2}{c}{ Post test } & \multirow{2}{*}{ Statistic } & \multirow{2}{*}{$\boldsymbol{P}$} \\
\cline { 2 - 5 } & $\mathbf{M}$ & SD & M & SD & & \\
\hline Sikap keseluruhan & 5.736 & 1.018 & 6.124 & 0,627 & 59.000 & $<.001$ \\
Sikap terhadap CU & 5.758 & 1.053 & 6.264 & 0.683 & 14.500 & $<.001$ \\
Sikap berwirausaha & 5.730 & 1.279 & 5.803 & 0.982 & -0.454 & 0.326 \\
\hline
\end{tabular}

Peningkatan sikap peserta terhadap CU, keinginan berwirausaha, maupun sikap secara keseluruhan setelah mengikuti kegiatan pengabdian masyarakat ini dapat terlihat pada gambar 1. Perubahan yang cukup signifikan terjadi pada sikap peserta terhadap CU dan sikap secara keseluruhan. Sedangkan, sikap peserta untuk berwirausaha mengalami kenaikan yang tidak begitu signifikan.

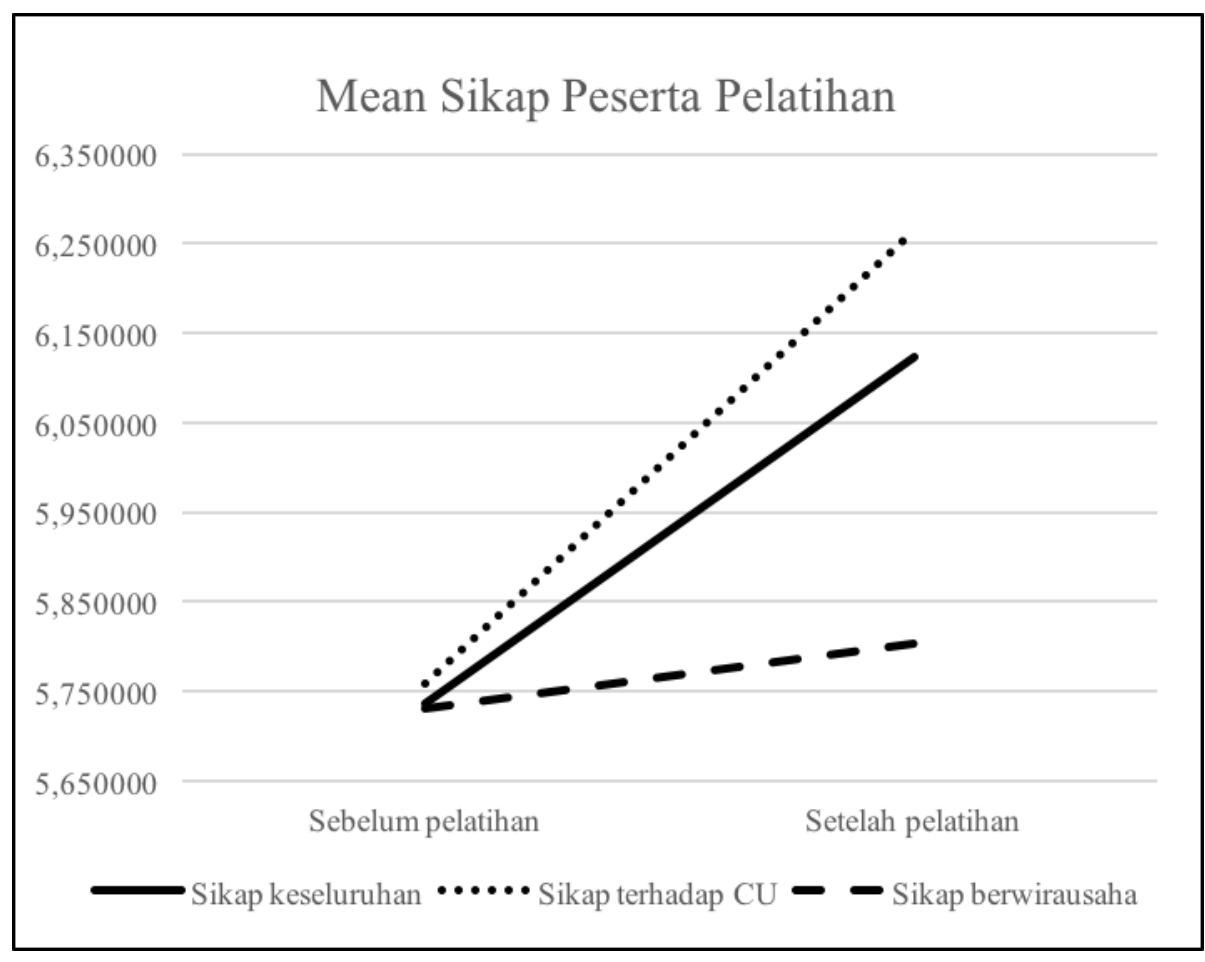

Gambar 1 Grafik perubahan sikap peserta pelatihan

Tabel 4 Analisis evaluasi reaksi

\begin{tabular}{clccc}
\hline No & \multicolumn{1}{c}{ Aspek } & N & Mean & Std. Deviasi \\
\hline 1 & Materi pelatihan & 49 & 4,5 & 0,5 \\
2 & Trainer & 49 & 4,6 & 0,6 \\
3 & Sarana pelatihan & 49 & 4,5 & 0,6 \\
4 & Pelaksanaan pelatihan & 49 & 4,4 & 0,6 \\
\hline
\end{tabular}


Berdasarkan hasil evaluasi kepuasan peserta (Tabel 4), skor evaluasi peserta pelatihan berkisar dari 4,4 hingga 4,6 dengan skor tertinggi yang dapat dipilih adalah 5. Dengan demikian, dapat disimpulkan bahwa sebagian besar peserta merasa sangat puas dengan pelatihan daring yang diadakan. Peserta merasa antusias dengan materi-materi yang diberikan.

Dari hasil analisis, diketahui bahwa program ini berhasil meningkatkan pengetahuan dan membentuk sikap generasi milenial yang positif terhadap CU dan keuangan. Dengan demikian, diharapkan generasi milenial dapat bergabung dengan atau memilih CU sebagai salah satu solusi finansial mereka. Kondisi ini tentu saja dapat menguntungkan kedua belah pihak. Generasi milenial memiliki lembaga yang menjadi tujuan investasi sekaligus memberikan pendidikan keuangan berkelanjutan. Di sisi lain, CU pun diuntungkan karena keterlibatan generasi milenial dapat menjamin kelangsungan usaha CU ke depannya. Dalam lingkup yang lebih besar, hubungan antara generasi milenial dan CU juga dapat menopang perekonomian Indonesia agar lebih kuat dan mandiri ke depannya.

Kegiatan yang kami lakukan ini dapat menjadi program awal (pilot program) yang terus disempurnakan dan dapat digunakan di daerah dan lembaga CU lainnya. Motivasi dan kesadaran yang datang dari dalam diri peserta terbukti dapat memengaruhi ranah kognitif seseorang, khususnya meningkatkan sikap atau penilaian positifnya terhadap $\mathrm{CU}$ dan literasi keuangan. Metode self-instructional training dan problem-solving therapy dapat dikembangkan dengan berbasis pada kekuatan ekonomi setempat untuk meningkatkan relevansi, daya tarik, dan efektivitas program tersebut. Apabila program ini dapat dikemas dengan lebih sempurna dan dijalankan dalam skala yang besar di seluruh Indonesia, kami optimis bahwa pandangan generasi milenial terhadap CU dan koperasi akan perlahanlahan berubah menjadi lebih positif, sehingga kelangsungan CU dapat terjamin ke depannya. Selain itu, perekonomian Indonesia akan menjadi lebih mandiri dengan prinsip gotong-royong.

\section{SIMPULAN}

Secara umum, program ini dapat berjalan dengan lancar dan cukup baik, walaupun terdapat sedikit perubahan desain kegiatan dari yang awalnya dilakukan secara luring menjadi secara daring karena adanya pandemi Covid 19. Program ini terbukti berhasil meningkatkan pengetahuan dan membentuk sikap generasi milenial yang positif terhadap CU dan literasi keuangan. Pemberian pelatihan 
Patria : Jurnal Pengabdian Kepada Masyarakat

ISSN : 2656-5455 (media online) Vol. 3 | No. 2 September 2021

106

self-instructional training dan problemsolving therapy diharapkan dapat membekali peserta dengan kemampuan menghadapi situasi sulit dengan efektif melalui instruksi dan motivasi diri.

Sebagian besar peserta melaporkan bahwa mereka puas dengan penyelenggaraan kegiatan ini. Namun, kegiatan ini masih memiliki beberapa kekurangan. Kegiatan ini berhenti pada pengukuran intensi perilaku (i.e: keinginan bergabung dengan $\mathrm{CU})$ dan bukan mengukur perilaku aktual peserta. Idealnya, kegiatan ini diikuti dengan follow up untuk memastikan peserta benar-benar mengalami perubahan mindset terkait CU. Tapi karena waktu pelaksanaan program yang terbatas, kegiatan follow up tidak dapat dilakukan.

\section{UCAPAN TERIMA KASIH}

Penulis mengucapkan terima kasih kepada LPPM Universitas Katolik Soegijapranata yang telah memberikan dukungan pendanaan sehingga kegiatan pengabdian masyarakat ini dapat terlaksana dengan baik. Penulis juga berterima kasih kepada pengurus CU Pelita Usaha dan CU PL Kasih yang telah memberikan dukungan dan asistensi sehingga kegiatan pengabdian masyarakat ini dapat terlaksana secara daring dengan lancar.

\section{DAFTAR PUSTAKA}

Ervina (2019). Koperasi di Indonesia dan Peranannya dalam Perekonomian. Dari: https://www.talenta.co/blog/insighttalenta/koperasi-indonesia/ pada 8 Oktober 2020.

Zulhartati, S. (2010). Peranan Koperasi dalam Perekonomian Indonesia. Guru Membangun, 25(3), 1-7.

Kemenpppa (2018). Statistik Gender Tematik: Profil Generasi Milenial Indonesia, Jakarta: Kementerian Pemberdayaan Perempuan dan Perlindungan Anak.

Alvara (2020). Indonesia Gen Z Anda Milennial Report 2020: The Battle Of Our Generation, Jakarta: Alvara.

Prayogo, C. (2019). Wajah Koperasi di Mata Milenial. Diunduh dari: https://www.wartaekonomi.co.id/rea d252435/wajah-koperasi-di-matamilenial pada 8 Oktober 2020.

IDN Research Institute (2019). Indonesia Millennial Report 2019, Jakarta: IDN Media.

Kirkpatrick, D. \& Kirkpatrick, J. (2006). Evaluating Training Programs: The Four Levels. San Francisco: BerrettKoehler Publisher.

Faulkner, A. E. (2015). A systematic review of financial literacy as a termed concept: More questions than answers. Journal of Business \& Finance Librarianship, 20(2), 7-26. doi:10.1080/08963568.2015.982446

Khan, M. T. I., Tan, S. H., \& Gan, G. G. G. (2018). Advanced financial literacy on Malaysian gen $\mathrm{Y}$ investors and its consequences. The Journal of Applied Economic Research, 13(1), 83-108. doi:10.1177/0973801018800085

Pangestu, S., \& Karnadi, E. B. (2020). The effects of financial literacy and materialism on the savings decision of generation Z Indonesians. Cogent Business \& Management, 7(1). 
Patria : Jurnal Pengabdian Kepada Masyarakat

ISSN : 2656-5455 (media online) Vol. 3 | No. 2 September 2021

doi:10.1080/23311975.2020.174361

8

Sundel, M., \& Sundel, S. S. (2005).

Behavior change on the human services: Behavioral and cognitive principles and applications. California, USA: Sage Publications, Inc. 